University of Warwick institutional repository: http://go.warwick.ac.uk/wrap This paper is made available online in accordance with publisher policies. Please scroll down to view the document itself. Please refer to the repository record for this item and our policy information available from the repository home page for further information.

To see the final version of this paper please visit the publisher's website. access to the published version may require a subscription.

Author(s): Mark Harrison

Article Title: Stalinist Industrialisation and the Test of War Year of publication: 1990

Link to published version: http://dx.doi.org/:10.1093/hwj/29.1.65

Publisher statement: None 


\title{
Stalinist Industrialisation and the Test of War*
}

\author{
Mark Harrison** \\ Department of Economics \\ University of Warwick
}

"Hindsight, usually looked down upon, is probably as valuable as foresight, since it does include a few facts" (Grace Paley, Later the Same Day, Harmondsworth, 1985, p 89).

"As every good historian knows, there are no free facts" (Maxine Berg, "Will the Real Bosses Please Stand Up: Marglin and Landes on the Origins of Capitalist Hierarchy," Warwick Economic Research Papers, no 305, University of Warwick, 1988, p 31).

* Published in the History Workshop Journal no. 29 (1990), pp. 65-84.

** Mail: Department of Economics, University of Warwick, Coventry CV4 7AL, UK. Email: mark.harrison@warwick.ac.uk. Earlier versions of this paper were presented to seminars at St Antony's College, Oxford, and the University of East Anglia. I am grateful to John Barber, Wlodzimierz Brus, Peter Gatrell, Michael Kaser, Peter Law, and the editors for helpful comments. 


\section{Stalinist Industrialisation and the Test of War}

The great Soviet victory over Germany in 1945 has often been cited as justification for the decade of whirlwind transformations which preceded the outbreak of war. Of all Stalin's policies, rapid industrialisation is the one which seemed most obviously validated by wartime experience. According to authoritative western estimates, between 1928 and 1941) the output of civilian industries multiplied 2.6 times, while munitions output grew 70 -fold. In these twelve years industry, construction and transport expanded their contribution to the national income from little more than one quarter to not far short of one half. ${ }^{1}$

A decisive factor in the war's outcome was the volume of munitions available to the armed forces of the opposed coalitions. These volumes far exceeded the previously accumulated stocks initially available to the combatant nations: they depended above all upon the specialised industrial capacities which each nation was able to assign to war production. The quantity and quality of combat munitions available to the Red Army on 22 June 1941 proved far less important than the capacity to replenish and expand them. This meant not only the specialised capacities of the defence industries but also the supporting infrastructure of general-purpose engineering capacity as well as the steel industry, nonferrous metals, the fuels, chemicals, energy and transport sectors. Without these, the Soviet armed forces could not have lasted more than a few weeks in combat with the Wehrmacht. Moreover, enhancement of the Soviet capability for supplying a protracted war of resources was not an accidental by-product of Soviet industrialisation, but was a deliberate element in the complex of goals set out in the transition period of $1928-31 .^{2}$

Stalin himself recorded absolutely no doubts on the contribution of his own prewar policies to victory. In a major speech of February 1946 he summed up the

\footnotetext{
${ }^{1}$ Calculated from Richard Moorsteen and Raymond P. Powell, The Soviet Capital Stock, 1928-1962, Homewood, Illinois, 1966, pp. 622-3 (Table P-1). All estimates are measured in rouble prices of 1937.

2 Julian Cooper, 'Defence Production and the Soviet Economy, 1929-1941', Soviet Industrialisation Project Series, no. 3, Centre for Russian and East European Studies, University of Birmingham, 1976; S. M. Tupper, 'The Red Army and Soviet Defence Industry, 1934-1941', unpub. PhD thesis, University of Birmingham, 1982; Mark Harrison, Soviet Planning in Peace and War 1938-1945, Cambridge, 1985, pp 46-7; R. W Davies, The Industrialisation of Soviet Russia, vol. 3, The Soviet Economy in Turmoil, 1929-30, Basingstoke, 1989, pp. 441-55.
} 
results of the war and evoked the theme of war as a national test. ${ }^{3}$ The war, he declared, had not been all bad because it had provided "a great school of testing and verification of all the people's forces ... an examination for our Soviet system, our state, our government, our Communist Party". The Soviet Union had passed this examination, thereby vindicating the Soviet social system, multinational state and armed forces against prewar critics and doubters. Essential to this was their prewar preparation. Victory in war was attributable not only to high Soviet morale, but also to material preparedness, making possible a high level of wartime supply of the Red Army. Behind the latter Stalin found the prewar policies of economic transformation: rapid industrialisation of the country, and the collectivisation of agriculture.

Industrialisation and collectivisation - and also one other aspect of the party's general line, its defence against internal opposition. For Stalin, victory in 1945 also provided sufficient justification for his prewar suppression of "the antiparty machinations of the Trotskyists and Rights". The war had vindicated the Soviet system and its policies against enemies at home, as well as against those abroad.

Stalin's views left a lasting imprint on Soviet historiography. ${ }^{4}$ The war would be seen as the heaviest, the most bitter, even the supreme test of the Soviet system and economy; it justified the prewar policies of forced industrialisation and collectivisation of agriculture, and demonstrated the superiority of the Soviet system above others in carrying out the tasks of both war and peace. Here would also be found a key element of continuity between today's 'new thinking' and more traditional views. For example, President (then General Secretary) Gorbachev spoke about the test of war on the occasion of the 70th anniversary of the October 1917 revolution in the following terms:

The aggression imposed upon us was a pitiless examination of the viability of the socialist structure, the fortitude of the multinational Soviet state and the strength of patriotic feeling of Soviet people. And we passed this examination by fire and sword, comrades! (Prolonged applause). ${ }^{5}$

And in a more measured analysis published at the same time, Gorbachev concluded:

... not to force industrialisation was impossible. Already from 1933 the threat of fascism began to grow. And where would the world have been, had the Soviet

${ }^{3}$ Pravda, 10 February 1946. Here Stalin echoed Marx, Lenin and Trotsky, as well as his own speech of November 1943 For relevant citations see Joseph Stalin, The Great Patriotic War of the Soviet Union, New York, 1945, p. 100; Marxism-Leninism on War and Army, Moscow, 1972, p 21; N. N. Azovtsev, V. I. Lenin i sovetskaya voennaya nauka (V. I. Lenin and Soviet military science), Moscow, 1981, p. 47; Silvana Malle, The Economic Organization of War Communism, 1918-1921, Cambridge, 1985, p. 475.

${ }^{4}$ For detail see Harrison, Soviet Planning, p. 243.

${ }^{5}$ M. S. Gorbachev, Oktyabr' i perestroika: revolyutsiya prodolzhaetsya (October and restructuring: the revolution continues), Moscow, 1987, p. 25. 
Union not stood in the path of the Hitlerite war machine? Our people destroyed fascism with the power created by them in the 1920s and 1930s. Had there been no industrialisation, we would have stood defenceless before fascism. ${ }^{6}$

\section{Forced Rapid Industrialisation}

In this paper I seek to evaluate the interwar Soviet programmes of industrialisation and collectivisation, and the associated creation of a new economic system, from the perspective of 1941-5. My focus is restricted to the economic, in a broad sense, and it ignores many political, social, military and diplomatic aspects of war preparation. I do not attempt to discover whether, with alternative policies, Soviet leaders might have averted the rise of Hitler or diverted Hitler's war.

This has a double excuse, if not justification. First, these topics are well covered elsewhere in many stimulating discussions. ${ }^{7}$ Second, whatever may be held to explain the failure of German aggression, the ultimate factor in Germany's defeat was the resources of the opposing coalitions: the volume of munitions produced on each side, multiplied by the intensity of their use in combat. ${ }^{8}$ The Second World War was a war of production. No other justification for a focus on the economic is required.

The Soviet Union's industrial capacity was quite clearly a foundation of its capacity for war. More difficult to establish is whether the particular pattern of prewar industrialisation for which the Stalinist leadership opted was in itself optimal, either in hindsight or given the objectives of the regime at the outset. Both temporal and spatial aspects of this pattern are at issue. It may be argued that the pace of the industrialisation process was too rapid, and that industrial capital formation was wrongly distributed across the Soviet land mass. Moreover, pace and distribution turn out to be connected, because it was pressure for rapid accumulation which

\footnotetext{
${ }^{6}$ M. S. Gorbachev, Perestroika i novoe myshlenie dlya nashei strany i dlya vsego mira (Restructuring and new thinking for our country and for the whole world), Moscow, 1987, p 35.

${ }^{7}$ John Erickson, The Soviet High Command: A Military-Political History, 19181941, 1962, and his Stalin's War with Germany, vol. 1, The Road to Stalingrad, 1975, vol. 2, The Road to Berlin, 1982; A. M. Nekrich, 1941, 22 iyunya (1941, 22 June), Moscow, 1965, Seweryn Bialer, Stalin and His Generals: Soviet Military Memoirs of World War 11, 1970. In 1987 Soviet historians began to reopen the issues of Stalin's war preparations and military leadership first raised in the 1960s. See an interview with A. M. Samsonov, 'Historian Faults Stalin as Military Leader', Current Digest of the Soviet Press, vol. 39, no. 12, 1987, pp. 5-6; A. M. Samsonov, Pamyat' minuvshego (Memory of the past), Moscow, 1988, pp. 212-14, N. Pavlenko, 'Na pervom etape voiny. Zametki voennogo istorika' (In the first stage of the war: comments of a military historian), Kommunist (Communist), no 9, 1988, pp. 88-94; D. Volkogonov, 'Nakanune voiny' (On the eve of war ...), Pravda, 20 June 1988.

${ }^{8}$ Raymond Goldsmith, 'The Power of Victory: Munitions Output in World War II', Military Affairs, vol. 10, Spring, 1946, p. 69.
} 
favoured the concentration of new capacities in the heavy and defence industries in traditional industrial centres vulnerable to invasion from the west.

We can proceed by first isolating the question of pace. Here economic historians have supplied ample confirmation that by peacetime standards the Stalinist industrialisation drive tried to do 'too much too fast.' The attempt to implement overambitious plans resulted in lost output and productive assets, under-utilised capacity, wasted investment, excessive mortality of the population and the destruction of skilled personnel. ${ }^{9}$ Less ambitious plans could have resulted in a variety of alternative outcomes characterised by industrial growth less than or equal to that actually achieved, combined with fewer social and economic tensions and higher morale of the population.

However, it does not follow that an alternative, less forced industrialisation pattern, better suited to peacetime tasks, would have automatically given better results in war as well. This is a proposition which goes beyond existing research and requires independent examination. The problem with it is that less ambitious plans for prewar industrial growth would have resulted not just in slower (if smoother) output expansion, but would have altered the composition of 1941 stocks of fixed capacity. There would have been less heavy industry in proportion to light industry, less public sector large scale industry in proportion to the private artisan sector, and generally less industry in proportion to agriculture and services. (At the same time it is possible that by 1940, with less wasteful economic growth, there could have been more of everything.)

Would the (probably) smaller industrial base of public sector defence output resulting from more peacetime attention to equilibrium and to civilian morale have constrained the Soviet war effort? The answer to this question is not clear cut. In a very abstract sense-yes: the outcome of the war is to be explained primarily by reference to the ability of the opposing sides to produce munitions in wartime, and anything which might have reduced the Soviet ability to supply the means of war must have lessened the chances of Soviet victory.

Nonetheless, might not a smaller wartime industrial base have been compensated in other directions-for example, by higher civilian morale and national unity? Alec Nove once suggested: 'it is quite false to use the result of the war as ex-post-factum justification of Stalinism. Perhaps, with less harsh policies, the greater degree of loyalty in 1941 would have offset a smaller industrial base? ${ }^{\prime 10}$ । find little safety in this argument. Morale and munitions were both required to fight the invader. There was limited scope for trading them off against each other; a more loyal population would have allowed more munitions to be supplied to the front (rather than diverted to policing the rear), and NKVD troops could have spent more time fighting the Germans, less time policing labour camps and minority nations.

\footnotetext{
${ }^{9}$ For example, Holland Hunter, 'The New Tasks of Soviet Industry in the Thirties', in Padma Desai (ed.), Marxism, Central Planning and the Soviet Economy. Essays in Honour of Abram Bergson, 1983, p. 196.

${ }^{10}$ Alec Nove, Was Stalin Really Necessary? 1964, p. 31.
} 
However, as the Russian experience of the First World War suggests, in the absence of munitions, loyalty would have proved a rapidly wasting asset.

\section{Industrialisation, its Pace and Concentration}

Compelling doubts about the positive results of forced rapid industrialisation for wartime economic performance arise only when this performance is examined in more detail. Here the central, obvious, yet still startling fact is that the Soviet Union fought the war's decisive battles with a capital stock no more than two-thirds the size of that already accumulated in 1940 . The gap reflects capacities lost or decommissioned as a result of the loss of territory to the invader. Thus the Soviet economy was denied access to a substantial share of the results of prewar industrial accumulation, yet still managed to sustain an outstanding wartime productive effort. Soviet industry could therefore have fought its war on the basis of a slower rate of prewar military-industrial expansion, but only on condition that its losses of capacity in the initial phase of the war could somehow have been more effectively limited than was in fact the case.

Why were the capacity losses of 1941-2 so severe? The heavy impact of territorial loss is attributable to two factors. One was the traditional concentration of Soviet heavy and defence industries in the southern and western regions of the European USSR; this created a deep vulnerability to invasion from the west-one which Soviet military and economic leaders were well aware of. And this was one reason for prewar policies of dispersal of strategic industries to the interior of the country. Such policies reflected in part economic considerations-a commitment to the industrialisation of relatively backward regions, a desire to reduce the interregional transportation of industrial materials and products and economise on transport costs. They were also the result of straightforward military-economic calculations - a recognition of the vulnerability to disruption of an economy with a high degree of regional specialisation, reliant upon a limited number of regional fuelmetallurgical complexes. But the other factor which helps to explain the heavy impact of territorial loss upon Soviet defence and heavy industries in 1941-2 is that, after an initial opening up of the interior regions under the First Five-Year Plan (1928-32), this policy was scarcely implemented in the prewar years; existing regional specialisations were maintained, and much unique capacity in military engineering and metallurgy was formed in zones of future German occupation. ${ }^{11}$

Why was the prewar policy of industrial dispersal not more vigorously implemented? The simple reason is, apparently, that it was too costly. It was expensive in terms of additional investment resources and a slower expansion of the resulting output, given the difficulties of capital construction and capacity operation in a remote, agrarian environment. The economic mechanism of forced industrialisation emphasised quick results and rewarded people for them. It always yielded quicker and cheaper results to locate new defence and investment goods

\footnotetext{
${ }^{11}$ Harrison, Soviet Planning, pp. 49-51.
} 
capacity in the already industrialized (but vulnerable) regions of the west and south. ${ }^{12}$

This is why the forced pace of Soviet industrialisation tended to inhibit industrial dispersal. However, it does not follow that industrial dispersal would have been any easier in combination with a slower, more relaxed pace of industrial expansion. The dispersal process would itself have been very costly in terms of opening up remote regions for transportation, power distribution, worker accommodation and consumer trade. It would have added to the capital costs of prewar industrialisation and made a more relaxed path still less attainable. Therefore, only with great difficulty could more vigorous dispersal of the country's military-industrial potential to the interior regions have been reconciled with a policy of reduced capital construction and slower, more balanced and consumer-oriented industrial growth in the prewar period.

Nonetheless, it seems a good bet that such a prewar policy combination would have paid off in wartime. For the Soviet people paid dearly for their leaders' prewar sin of omission in the field of industrial dispersal. They paid by having to carry dispersal out under incomparably more difficult conditions, when war had already broken out and invading forces were already deep inside Soviet territory.

This is the story of the industrial evacuations, of which there were two - the big one of July-November 1941 and a much smaller one limited to the southern sector in June-September 1942. The big one involved up to one eighth of all Soviet industrial assets, including the bulk of the country's defence plant and many key enterprises of the metallurgical, chemical, engineering and electricity supply. Evacuation tasks were assigned top priority-equal to that of fighting the enemy. Huge resources of transport and construction were diverted to its implementation. The centre of gravity of the Soviet Union's industrial economy was shifted bodily from Europe to the Urals and western Siberia. In this way the results of territorial loss were mitigated, the Soviet defence capacity was saved and economic collapse averted. $^{13}$

From a conservative standpoint it could be argued (and is in fact implied, more or less openly) that what was achieved in wartime could never have been imposed in time of peace-that the 'incomparably more difficult circumstances' generated greater effort, greater self-sacrifice, greater heroism on the part of the workers. Thus, in connection with one outstanding-yet typical-feat of industrial dispersal,

${ }^{12}$ In the first edition of his Ekonomika SSSR v period Velikoi Otechestvennoi voiny), (The economic system of the USSR in the period of the Great Patriotic war), Moscow, 1965, Ya. E. Chadaev attributed the preference for quick results to 'narrowly bureaucratic (usko-vedomstvennye) interests' (pp. 59-60). However, in the second (1985) revised edition of the same work an entire section of critical comment was omitted; instead, Chadaev asserted that the Soviet military-economic potential was 'rationally located' (pp. 73-4; see also pp. 45-7)

${ }^{13}$ For more detailed accounts see Sanford R. Lieberman, 'The Evacuation of Industry in the Soviet Union during World War II', Soviet Studies, vol. 35, no. 1, 1983; Harrison, Soviet Planning, pp. 63-81. 
the rapid relocation of a Moscow steelworks in the Urals in the freezing winter of 1941, the wartime commissar for construction S. Z. Ginzburg has recalled:

Of course, by customary standards to build a large scale factory in heavy industry in 75 days is impossible. It was natural that even some experienced builders were dubious about it. But life demonstrated that even in an extremely compressed construction schedule one can seek out reserves and achieve what seemed impossible. ${ }^{14}$

And generally it seems to be true that during the war Soviet enterprises worked with greater 'tautness', with a lower safety margin, concealed fewer reserves, and calculated their options with less self-regard than in peace time. ${ }^{15}$ Given this piece of hindsight it could be argued that postponement of industrial dispersal until the outbreak of war was rational and saved resources; had the same relocation of capacities been attempted in the late 1930s, it would have taken many years to complete with almost indefinite postponement of results.

In my view this defence of the prewar industrialisation pattern is unacceptable for two reasons. One is that the wartime evacuation of industry, while justly celebrated as an outstanding feat of heroic labour, was only a first step in repairing the damage caused by invasion; it certainly did not solve all the resulting problems, and even after its conclusion the economy of the interior regions still hung over the brink of a precipitous collapse in 1942. The economic crisis of that year was in many ways deeper than that of the first post-invasion months; the country's defence capacity had been saved, but its civilian economy had been reduced to the most dreadful shambles, and this in turn posed a deadly threat to the continuity of defence output. The evacuation contributed to this imbalance because of the demand piled upon demand for transport, electric power and material supplies from the thoroughly inadequate infrastructure of the remote regions in which the country's strategic enterprises had been relocated. If the cost of resolving this crisis were calculated, the result would surely show that deferment of industrial dispersal until war had broken out was an expensive choice, not a choice for dispersal 'on the cheap'.

The other reason why prewar industrial concentration followed by wartime dispersal must be rejected as a rational policy combination is that this argument follows well-worn Stalinist tradition in making a virtue out of bitterest necessities. If there is an argument here, it is that the perestroika of the late 1980s is already half a century overdue. This is what would have supplied the conditions necessary for costeffective war preparation-to have created in advance a peacetime economy in

\footnotetext{
${ }^{14}$ S. Z. Ginzburg, 0 proshlom-- dlya budushchego (About the past--for the future), Moscow, 1983, p. 230.

${ }^{15}$ For the formal inference (that in wartime Soviet enterprises operated with lower reserves and increased tautness) and for a brief discussion of it, see David Dyker's review of Harrison, Soviet Planning, in Slavonic and East European Review, vol. 65 , no. 2,1987 , pp. 308-9.
} 
which enterprises and construction projects tended spontaneously to efficient capacity utilisation, without need for a safety margin as a defence against planning uncertainty, without concealment of reserves. Then the intended dispersal of new capacities of strategic significance to the interior regions would have been implemented within a reasonable planning horizon.

Could the war have been fought without more prewar industrial dispersal, still on the basis of a lower rate of prewar industrial accumulation and smaller initial military-industrial capital stock, by means of adoption of alternative policies when war had already broken out? Could Soviet industries have been either defended or evacuated more effectively in 1941-2? This also seems possible, although not without question.

It is possible that better Soviet foresight in 1941-2 might have mitigated the capacity losses which "Barbarossa" would impose on Soviet industry. In June 1941 Hitler succeeded in fooling Stalin both over the likelihood of a German attack, and over its principal direction. Stalin believed that, if war should come, the main weight of the German blow would be felt in the south west, on the Ukrainian front, not in the Moscow direction. ${ }^{16}$ And in the spring of 1942 Stalin fell victim to a second deception, designed to persuade him that the German summer offensive would be directed at Moscow once more, not in the southern (Stalingrad) sector. ${ }^{17}$

Had Stalin not been deceived, then things would have gone better. How much better, it is again impossible to say, for even when Soviet military leaders were completely familiar with Hitler's plans and the requirements of strategic defence against them, the Wehrmacht was still able to storm through Soviet defences, carry out large scale encirclements and inflict further massive losses of territory. ${ }^{18}$

Perhaps the Stalinist political system's excessive centralisation and intolerance of alternative perspectives made it especially vulnerable to German deceits. But deception and surprise were weapons of war like any other; each side designed their weapons to exploit the adversary's weaknesses, and only hindsight was fully proof against them. After all, in December 1941, it was the turn of the democratically governed United States to fall victim to a Japanese campaign of deception and surprise, in spite of many accurate forewarnings of Japanese intentions.

Could a more effective industrial evacuation have saved a higher proportion of Soviet initial capacities in military and supporting industries? On this question I am more sceptical. It is easy to demonstrate that the real process of Soviet industrial evacuation in face of the enemy (and often under fire) was ill prepared, chaotic and costly. It is more difficult to show that there was some smoother, more coordinated response available under these immensely difficult conditions. A group of Leningrad historians has argued recently that control of the evacuation process in 1941 was excessively centralised; this resulted in delayed decisions, failure to commit sufficient transport capacities to evacuation and avoidable losses of assets to the

\footnotetext{
${ }^{16}$ Pavlenko, 'Na pervom etape', 1988, p. 90.

${ }^{17}$ Samsonov, Pamyat' minuvshego, 1988, pp. 397-8.

${ }^{18}$ Bialer, Stalin and His Generals, 1970, p. 584.
} 
enemy. ${ }^{19}$ But the evidence of delays and shortages can be interpreted just as easily to suggest that the main constraint on timely evacuation was the overall shortage of workers and rolling stock, which could not have been improved by prompt administrative action. In any case, experience on the southern front in 1942 showed that, when the organisational requirements of evacuation before invading forces were already fully understood, the same frictions asserted themselves and enforced disorganisations and losses similar to those of $1941 .{ }^{20}$

In summary, the achieved level of Soviet industrial development was, in a broad sense, one of the keys to Soviet victory in 1941-5. However, the argument that forced rapid industrialisation on the Stalinist pattern was required for this is hard to sustain in detail. This pattern entailed huge costs in both peace and war. The costs of peace time were the heavy sacrifices and losses arising from its 'extensive' character and the command-administrative relations which enforced it. When war broke out an additional price was paid in terms of the regional concentration of strategic enterprises (which was a direct function of the prewar forced pace of industrial construction), the effort of having to carry out in war time the tasks of dispersal which should have been carried out in time of peace, and the sacrifice of the fruits of prewar capital construction which remained on occupied territory and could not be saved.

It may be that, from the point of view of the needs of war in 1941-5, the case for a degree of forced-march industrialisation in the prewar years cannot be entirely discounted. However, the real extent to which the pace was forced under Stalinist policies looks, in retrospect, counter-productive.

\section{Collectivisation and Industrialisation}

Was the prewar policy of farm collectivisation validated by Soviet victory in 1945 ? This question may be considered under two different headings. First, was farm collectivisation a necessary condition of the prewar industrial accumulation underlying Soviet defence in 1941-5? Here I shall be concerned primarily with collectivisation in relation to the real path of Soviet industrial expansion-not to some hypothetical alternative, however preferable. Second, how well did collective agriculture meet the needs of wartime food policy? These questions are dealt with in order. The first of them may seem distant from the 'test of war', but the role of collective farming in peace time and the nature of the agrarian transition will throw essential light upon wartime processes.

The role of collectivisation in support of Soviet industrial expansion has been much discussed among western historians, and usually to the discredit of Stalinist agrarian policy. Forced industrialisation and the transition to a shortage economy in

\footnotetext{
${ }^{19}$ M. I. Likhomanov, L. T. Pozina and E. I. Finogenov, Partiinoe rukovodstvo evakuatsiei v pervyi period Velikoi Otechestvennoi voiny 1941-1942 gg. (Party leadership of the evacuation in the first period of the Great Patriotic war, 1941-2), Leningrad, 1985, pp. 79-80.

${ }^{20}$ Harrison, Soviet Planning, pp. 63-81.
} 
1928-9 had made a break in the market relationship with the smallscale peasant farmers inevitable. However, economic historians have confirmed that, in the process of replacing this market relationship, the basis for industrial accumulation was at least not widened and was arguably reduced. ${ }^{21}$

The damage done was both immediate and long term. The immediate damage was not done by collectivisation narrowly defined. It is worth noting that 'collectivisation' is often used to conflate three distinct elements in the agrarian transformation of 1929-30 and subsequent years: the transition to compulsory procurement of foodstuffs; the 'liquidation of the kulaks as a class' (i.e. the expropriation, deportation and eventual confinement in forced labour camps of the richer peasant families and those who sided with them); and the amalgamation of small peasant farms into large collectives (kolkhozy). In the short term, the worst damage was done by the first and, arguably, the second of these. ${ }^{22}$

The most important problem of procurement policy was that the authorities did not know when to stop; the procurement campaigns stripped the countryside of food stocks and brought about a profound crisis of rural subsistence for both the human and animal populations from which Soviet agriculture had barely recovered in $1941 .{ }^{23}$ Nor were the effects limited to agriculture, as the halving of the urban real wage in 1928-32 bore witness. More modest procurements under the First Five-Year

${ }^{21}$ This is a product of arguments by a number of western scholars (R. W. Davies, Michael Ellman, James R. Millar, S. G. Wheatcroft and others) derivative of research by the Soviet economist A. A. Barsov, and of S. G. Wheatcroft and R. W. Davies (eds), Materials for a Balance of the Soviet National Economy, 1928-1930, Cambridge, 1985. For a full bibliography up to 1984 see Mark Harrison, 'Primary Accumulation in the Soviet Transition', Journal of Development Studies, vol. 22, no. 1, 1985, pp. 1013. For a more recent contribution see Holland Hunter, 'Soviet Agriculture With and Without Collectivization, 1928-1940', Slavic Review, vol. 47, no. 2, 1988, pp. 203-16.

${ }^{22}$ An opposite view is supported by James R. Millar in 'Mass Collectivization and the Contribution of Soviet Agriculture to the First Five-Year Plan', Slavic Review, vol. 33, no. 4, 1974, p. 765, and in his 'Views on the Economics of Soviet Collectivization of Agriculture: The State of the Revisionist Debate', in Robert C. Stuart, ed., The Soviet Rural Economy, Totowa, N.J., 1984, p. 116: 'The contributions attribute[d] to collectivization belong instead to the introduction of the predatory agricultural procurement system-which helped to limit the losses collectivization brought about and thus raised the share of marketed output in the face of a decline in total output. While it is undoubtedly true that staunching the flow of blood from a severed artery is a "contribution" to health of the patient, the wound itself is not. Collectivization and the Stalinist agricultural procurement system of the 1930s stand in an analogous relation to one another.' Livestock killing, however, had begun in 1928 before the resort to mass collectivisation; its dynamic over 1928-32 reflected the steadily rising pressure of procurements, not the wildly fluctuating policy towards the kolkhoz.

${ }^{23}$ Stephan Merl, Der Agrarmarkt and die Neue Oekonomische Politik (The rural market and the New Economic Policy), Munich, 1981, p. 466. 
Plan would have smoothed out the behaviour of the real wage and left the economy in better shape for the second and third plan periods.

The accompanying resort to farm collectivisation had many motives. One of them was clearly a desire to back up the procurement system by centralising physical controls over peasant production. As it was, the kolkhoz regime not only failed to limit the worst effects of excessive procurements, but also imposed further distortions and losses on the agrarian system. First, to innovate and diffuse a functional model of the kolkhoz took time, requiring a wasteful process of radical experimentation and adaptation and resulting in further losses before the emergence of a workable institutional form. ${ }^{24}$ Second, in the kolkhoz which emerged, the relationship between output success and personal reward of the agrarian population was broken by two means: by the prior claim of the state on kolkhoz output, and by the workpoint system which made distribution of the residual to kolkhoz households proportional to labour inputs, not outputs. Third, in the process the rural population was brutalised and demoralised, decimated by famines and deportations. It is hard to imagine a worse preparation for invasion than the special hardships resulting for the rural populations of Belorussia, the Ukraine and North Caucasus.

Given forced industrialisation and the transition to a shortage economy based on nonprice controls, some alteration of the market method of allocating food surpluses was probably inevitable. However, in 1929-30 there were undoubtedly available approaches to handling food procurements and distributing manufactured consumer and investment goods to the rural population and farms which fell short of unrestricted confiscation of food stocks and comprehensive collectivisation of assets. Such more limited measures were already being implemented in the period January 1928-November 1929.

It is true that the problems associated with these more limited measures were many and deep rooted. A more smallscale, decentralised agrarian system would still have been difficult to administer in the 1930s under conditions of a shortage economy. Not least would have been the problem of devising reliable institutional limits on compulsory procurement of foodstuffs from the rural community. Nonetheless, as the postwar experience of eastern European countries has demonstrated, such problems can be lived with, and are not necessarily greater than those of a collectivised farm system. In fact, even with the forced pace of industrialisation as an unalterable given, a less radical agrarian policy in 1929-30 would have endowed the Soviet economy of the next decade with two great benefits. First, it would have deployed more agricultural resources, and the famine of 1932 would have been averted. Second, without mass deportations, the associated hypertrophy of the security organs and proliferation of labour camps would not have reached the same critical momentum.

Naturally, if we take into account the case already presented for industrialisation on a more balanced model (in respect of both pace and

${ }^{24}$ E.g. R. W. Davies, The Industrialisation of Soviet Russia, vol. 2, The Soviet Collective Farm, 1929-30, Basingstoke, 1980. 
distribution) from the point of view of the needs of war encountered in 1941-5, then the case for Stalinist radicalism in agrarian policy in 1929-30 is retrospectively weakened still further.

\section{Collective Agriculture in War Time}

Whether the collectivisation process had positive or negative significance for prewar Soviet industrial growth, authoritative figures in the Soviet Union continue to claim that the kolkhoz itself was validated by wartime experience. ${ }^{25}$

Direct evidence on this question is to be found in Soviet agriculture's wartime operation. The context was one of the most drastic destabilisation of the food balance. First, the outbreak of war meant an immediate withdrawal of millions of men from agriculture through territorial losses and, on the remaining territory, mobilisation into the army and munitions production. As a result, between January 1941 and January 1943 the kolkhoz workforce fell from 35 to 15 millions.

Men at the peak of their productive and political activity figured largely in the missing 20 millions. In January 1941, in the interior regions not subject to enemy occupation, able-bodied adult men made up one third of kolkhoz 'labour resources' (which included youths, pensioners and unfit workers). By January 1944 their share had fallen to one eighth. Able-bodied adult women outnumbered them by four to one. The proportion of youths, pensioners and unfit workers had risen from one quarter to one third. ${ }^{26}$

${ }^{25}$ While admitting that the collectivisation process carried substantial costs, both Gorbachev and V. S. Murakhovsky, then chairman of the State Committee for the Agroindustrial Complex (Gosagroprom, now defunct) reasserted this view during 1987. In an interview Murakhovsky remarked, 'Pravda recently did a good job, in my opinion, of describing the real costs of collectivization ... I see no need to repeat it. I will only say that I myself am firmly convinced that were it not for collectivization, the country could not have withstood such a horrible war' -- see 'Was Collectivization the Only Choice?', Current Digest of the Soviet Press, vol. 39, no. 33, 1987, p. 8. As for Gorbachev, according to Martin Walker ('Stalinist Skeletons', The Guardian, 2 November 1987), the first hardback edition of his Perestroika novoe myshlenie, 1987, which had just appeared, contained the words: 'The collectivisation of agriculture was a great historic act ... Yet, it proceeded painfully, not without serious excesses and blunders in methods and pace, but further progress for our country would have been impossible without it. If it had not been for collectivisation, we could have died from hunger in the war.' But when the paperback edition, dated December 1987, reached this country, the final sentence of this passage ( $p .36$ ) had disappeared.

${ }^{26}$ Calculated from 'Uchastie kolkhoznikov v obshchestvennom khozyaistve kolkhozov za gody Otechestvennoi voiny' (Participation of collective farmers in the social economy of collective farms in the years of the Patriotic war), Istoricheskii arkhiv (Historical Archive), no. 6, 1962, p. 29. 
This posed two kinds of problems. On one side was the problem of farm viability, as brigades and workteams were stripped of young males. On the other side was the problem of the political morale of the agrarian population. This was arguably both a cause and a result of the collapse in the kolkhoz population. Disaffected kolkhozniki in the western areas had welcomed the invader; in the interior, the kolkhoz network had been stripped of its party activists and (in the eyes of the authorities) was threatened with political demoralisation and organisational degeneration. The response was a return to administered political guidance from above through reintroduction of political departments (politotdely) in the MTS and sovkhoz systems. The politotdely remained in being until completion of the spring sowing after victory at Stalingrad. Soviet historians dispute their effectiveness; one has argued that their abolition in May 1943 was premature, while another considers that they should never have been established in the first place. ${ }^{27}$

The second factor impacting upon the food balance was that, while the population on Soviet controlled territory fell to two thirds of its prewar level in 1942, agricultural output collapsed to just one third that of 1940 in 1942-3. At the same time, official procurements of cereals and meat were significantly intensified. ${ }^{28} \mathrm{As}$ a result the armed forces and munitions workers got by, mainly on bread; everyone else (including the rural population) went through very hard times, and many starved. The rural emergency took longer to correct than downturns in other sectors; in 1943, when the rest of the war economy was registering improvements in output and the degree of coordination, agriculture remained in an utterly dreadful state, and as late as 1944 those active in food procurement campaigns were still

${ }^{27}$ For a positive account see I. I. Vinogradov, Politotdely MTS i sovkhozov v gody Velikoi Otechestvennoi voiny (1941-1943 gg.) (Political departments of machine and tractor stations and state farms in the years of the Great Patriotic War (1941-1943)), Leningrad, 1976; for a survey of conflicting views (including the critical opinions of Arutyunyan and Zelenin), with approval of Vinogradov's conclusions and of the hypothesis of premature abolition see V. T. Aniskov, Podvig Sovetskogo krest'yanstva v Velikoi Otechestvennoi voine. Istoriograficheskii ocherk (The feat of the Soviet peasantry in the Great Patriotic war: an historiographical essay), Moscow, 1979, p. 106.

${ }^{28}$ Procurements can be estimated as per cent of wartime output as follows

$\begin{array}{lrrrrrr} & 1940 & 1941 & 1942 & 1943 & 1944 & 1945 \\ \text { Grains } & 38 & 43 & 47 & 43 & 44 & 43 \\ \text { Meat } & 43 & 36 & 68 & 67 & 55 & 47\end{array}$

These are calculated from output series and procurement shares in Istoriya Velikoi Otechestvennoi voiny Sovetskogo Soyuza 1941-1945 gg. (History of the Great Patriotic war of the Soviet Union, 1941-5), vol. 2, Moscow, 1961, pp. 521-3, vol. 6, 1965, pp. 67-9; Istoriya vtoroi mirovoi voiny 1939-1945 (History of the Second World War, 1939-45), vol. 3, Moscow, 1974, p. 378, vol. 7, 1976, p. 51, vol. 9, 1978, p. 392, vol. 11, 1980, p. 344. Liveweight meat procurements are measured against deadweight output. 
being decorated for services equivalent to heroism under enemy fire. ${ }^{29}$ It is acknowledged that the intensity of procurements became counterproductive at times; not only was resistance stimulated but, for the sake of plan fulfilment, kolkhozy even contributed their seed stocks to grain collections; in the sowing season they had to borrow seed back from the state, and the two-way traffic in grain also represented a double burden on scarce transport resources? $?^{30}$

The kolkhoz system bowed under the strain. In some respects the agrarian regime was intensified. This was marked by regulations increasing the compulsory minimum of workpoints to be performed by individual kolkhozniki by 20-25 per cent. (The very existence of these minima, introduced in 1939, testifies to the very low level of economic reward of the collective farmer even in peace time.) In some cases kolkhozy adopted their own still higher compulsory minima. ${ }^{31}$ In the interior of the country kolkhoz sowing plans were sharply increased to compensate for the loss of arable land on territories captured by the enemy.

There is no consensus regarding the effectiveness of these wartime reinforcements of the kolkhoz system. According to a critical commentator the extension of sowings in the interior was counterproductive, given the overburdening of kolkhoz labour and in the absence of other material conditions (machinery and so forth); increasing the workpoint minima was also ineffective since they proved either unnecessary or unenforceable. ${ }^{32}$ However, these measures have won approval in subsequent, more conservative accounts. ${ }^{33}$

In other respects, the wartime regime on the kolkhoz was softened. Most significant here were relaxation of the principle of the state's prior claim on kolkhoz output and income, and the restoration of the link between output and household reward, especially in 1941-2. Such measures were often associated with harvesting, for example, in the extreme situation of 1941 the promise to harvest workers in the frontline regions of a half share in the harvest; in 1942, guarantees to harvest

${ }^{29}$ Istoriya Velikoi Otechestvennoi voiny, vol. 4, 1962, pp. 602-3.

${ }^{30}$ Yu. V. Arutyunyan, Sovetskoe krest'yanstvo v gody Velikoi Orechestvennoi voiny (The Soviet peasantry in the years of the Great Patriotic war), 2nd edn, Moscow, 1970, pp. 202-4.

${ }^{31}$ Vinogradov, Politotdely, p. 85; Alec Nove, 'The Soviet Peasantry in World War II', in Susan J. Linz (ed.), The Impact of World War II on the Soviet Union, Totowa, N.J., 1985, p. 80.

${ }^{32}$ Arutyunyan, Sovetskoe krest'yanstvo, 1970, pp. 19-20, 86-96.

${ }^{33}$ The impact of raising the compulsory minimum of workpoints is approved by Vinogradov, Politotdely, pp. 85-8; he argues that the main impact of the regulations was moral, 'therefore, in spite of the severity of the laws of the war period, administrative measures against those underperforming the workpoint minimum were a rare occurrence.' An intermediate position on the extension of sowings in the interior regions is endorsed by Aniskov, Podvig sovetskogo krest'yanstva, 1979, pp. 99-103: it was an emergency measure of compulsion dictated by the needs of survival and danger of further territorial loss, and did not reflect efficiency considerations or the strengthening of the kolkhoz system. 
workers (kolkhozniki and MTS employees) of a percent share in above-plan harvests and yields. ${ }^{34}$ New bonus systems were also being created to cover non-harvest tasks. A feature of all these schemes was the possibility of extending them to nonmembers of the kolkhoz: children and family relatives whose labour could be credited to kolkhoz members' workpoints, and outsiders who could be simply paid in kind. $^{35}$

In theory, kolkhoz members were 'more free' to dispose of some kinds of allotment produce of which the proportion claimed by official procurements declined in war time. This 'freedom' was enhanced by rapid inflation of kolkhoz market prices and a shift in the unregulated market terms of trade in favour of foodstuffs. But the freedom was very much an illusion. Offsetting it were the sharp decline in the absolute volume of allotment surpluses available for sale, and the quantity rationing of industrial goods. The main result, Nove comments, was that a small minority of peasants became paper rouble millionaires. ${ }^{36}$

More difficult to assess are the accounts of informal and extralegal relaxation of kolkhoz rules, which amount to a trend towards creeping privatisation of the collective farm itself. Reported breaches of the kolkhoz Statute relate first to the interior regions early on in the war, when the skilled and qualified core of productive and administrative workers was suddenly withdrawn from agriculture for other wartime employment; then to the territories subsequently reclaimed from German occupation; but such breaches were evidently more common and persistent than that implies, and took place throughout the country and throughout the war years. ${ }^{37}$ A sign of this was the severity of measures adopted after the war (in September 1946) to combat them. The most important deviations from rule were evidently the encroachment of family sowings on kolkhoz land, distribution of kolkhoz assets to households and the decline of the kolkhoz assembly as a focus of productive and political mobilisation of the kolkhozniki. ${ }^{38}$

If we turn to speculate on the minimum conditions of wartime success in agrarian policy, two things emerge. One is the necessity of some element of interfamily cooperation because, without it, most households would have been unable to sustain the loss in 1941 of key family members and livestock assets. Another is the system of compulsory procurement of food surpluses because otherwise, given the drying up of wartime supplies of industrial goods to the rural population, food producers would have tended to withdraw from the market.

${ }^{34}$ Istoriya Velikoi Otechestvennoi voiny, vol. 2, 1961, p. 165.

${ }^{35}$ Vinogradov, Politotdely, pp. 83, 89.

${ }^{36}$ Nove, 'The Soviet Peasantry', 1985, p. 85.

${ }^{37}$ E.g. Vinogradov, Politotdely, pp. 82-3.

${ }^{38}$ Direktivy KPSS i Sovetskogo Pravitel'stva po khozyaistvennym voprosam (Directives of the Communist Party of the Soviet Union and Soviet Government concerning economic questions), vol. 3, Moscow, 1958, pp. 91-7 (O merakh po likvidatsii narushenii Ustava sel'skokhozyaistvennoi and' v kolkhozakh' (On measures for liquidation of violations of the charter of agricultural association on collective farms)). 
Without these two (that is, with a completely decentralised and unregulated system of peasant production), Soviet agriculture in 1941 would surely have repeated the fate of the prerevolutionary Russian farming sector in 1916-17, when the decline in marketings far outpaced the loss of sown area and reduction in yields. ${ }^{39}$

However, neither the kolkhoz system, nor the system of unrestricted confiscation of food 'surpluses', was validated by the great victory of 1945. Where the kolkhoz regime was intensified, the results were arguably adverse; some of its key features had to be relaxed. When the relaxation took forms unwanted by political authority, costly administrative resources had to be diverted from the war effort to bolster the kolkhoz system. Some other less radical system of agricultural cooperation, more traditional in conception, less damaging in implementation and less dysfunctional in operation, with food procurement subject to restrained compulsion, would have done instead. The lessons of war for the kolkhoz system are, therefore, not differentiated from the results of its evaluation in peace time.

\section{The Economic System}

The process of implementing Stalinist industrialisation and collectivisation also threw up, as a kind of by-product, a new economic system. How successfully did this system measure up to the needs of warfare in 1941-5?

The economic system comprised two aspects, the boundaries between and relative importance of which were constantly shifting in the period as a whole. One was the formal system of management, of state and cooperative ownership subject to government controls: complex and differentiated, hierarchical and multi-level, bureaucratic and rule-bound, expanding from year to year by regular and predictable increments. The rules of the formal management system were biased towards expansion because, right from the start, they gave priority to physical output over financial indicators of enterprise performance. The formal system also regulated the expansion process from the top down, by means of detailed, centralised and comprehensive plans of the 'railway timetable' model and both quantity and price controls on supply and demand.

The informal management system was quite different: simplified and direct, cutting across bureaucratic levels and departments with direct, personal relationships of unrestricted authority and subordination. It thrived on excitement and emergency, an atmosphere of unique and unrepeatable events. Those who managed the informal system were impatient of rules and long term perspectives, balances and cost-benefit evaluations and tended to rely instead upon key priorities and political campaigns of mass mobilisation aimed at achieving results regardless of cost. They ruled by decree, rather than on the basis of expertise and consent. Rather than being centralised in a strict sense, the informal system focused economic management on a set of branch and regional priorities, each the responsibility of

\footnotetext{
${ }^{39}$ Maurice Dobb, Soviet Economic Development Since 1917, 6th edn, 1966, p.
} 71. 
one or another personal leader, and each developing on lines of maximum selfreliance or even production autarky.

The informal system was not more 'real' than the formal one, which was not just a paper creation; both really existed, or more strictly they coexisted and codetermined the outcome of events. However, Soviet accounts of wartime economic experience tend to conflate the attributes of the two systems: they stress the Soviet economy's exceptional mobil'nost' (its manoeuvrability, its outstanding record of mobilising resources for the war effort), but they attribute this to the formal system of planning and centralisation based on social ownership of productive means; here also is identified a source of the superiority in war of the Soviet over other kinds of economy..$^{40}$ In fact, the record of 1941-5 shows that, in the first and most dangerous period of the war, when the Soviet economic structure changed most rapidly, it was the informal system which predominated. The evacuation programme to save defence industry assets in frontline regions, the emergency programmes for conversion of industry to wartime needs and to mobilise the working population into the armed forces and war work were managed by means of high-level personal initiatives and individual improvisation, reinforced by decrees and dictatorial powers and supported by popular mobilisations. ${ }^{41}$

Without the informal management system, adaptation of the Soviet economy to the needs of the Second World War would have taken too long, or would never have been achieved. This adaptation could not have been managed on the basis of a 'railway timetable' type of conversion plan. The emergency situation of 1941 was simply not amenable to detailed foresight or the comprehensive planning of every nut and bolt.

At the same time, the positive role of the informal system in 1941-2 must be qualified in two respects. First, in military-political management this was the very same system which had performed so desperately badly in failing to foresee German strategic designs and in preparing the Soviet military, economy and society for the true character of the coming war. This failure of foresight went far beyond the lack of comprehensive, detailed contingency plans, and was reflected in the Stalinist leadership's excessive reliance on Hitler's guarantees, in its complacent faith in the ability to deter German aggression, in its arbitrary repression of alternative diplomatic forecasts and military plans for defence in depth, and in its failures of industrial dispersal.

The second qualification to the role of the informal system in 1941-2 is that its managers did not know when they had gone too far, when to stop. In 1941 they had saved the country's munitions capacity and safeguarded the conditions of time and space for a sustained military-economic mobilisation. But to sustain the mobilisation

\footnotetext{
${ }^{40}$ For authoritative examples see !storiya Kommunisticheskoi partii Sovetskogo Soyuza (History of the Communist Party of the Soviet Union), vol. 5(i), Moscow, 1970, pp. 274-5; Istoriya sotsialisticheskoi ekonomiki SSSR (History of the socialist economic system of the USSR), vol. 5, Moscow, 1978, pp. 175, 178, 185; Istoriya vtoroi mirovoi voiny, vol. 12, 1982, pp. 161, 166, 170.

${ }^{41}$ Harrison, Soviet Planning, pp. 100-2.
} 
was itself beyond them. Instead, they allowed the disproportions in the economy to rise to an unbearable degree of tension. In the winter and spring of 1941/42, although the front had been stabilised and munitions production was rising rapidly, the economic crisis actually worsened. Aside from munitions, the rest of the economy was in an utter shambles, and the production of steel, power, transport services and food (all of which were ultimately vital to maintenance of the country's fighting strength) was reduced to a small fraction of prewar norms. By 1942 the economy had become over-mobilised, with too many soldiers in uniform and too many war workers compared to the numbers remaining in civilian employment. ${ }^{42}$

The 'planned character' of the Soviet economy in wartime emerged out of the struggle to overcome this excessive mobilisation and to stabilise the civilian economy. The process of rationalisation was worked out pragmatically and, in the process, significant costs were incurred. During 1942 the situation of the basic industries (iron and steel, chemicals, fuels and power) and engineering was brought back to an even keel-by means of centralised, high-level fiat, but based on a priority schedule more sophisticated than the crude rankings of 1941 (defence industry 1-A, everything else 4-F), which was worked out and enforced by central planners. As the national product began to recover from the post-invasion trough, newly available resources were directed to expanding civilian production rather than to munitions output or resources for immediate combat. In economic management, personal dictatorship and rule by decree were being circumscribed by reassertion of formal management, and after the close of 1942 their role diminished. ${ }^{43}$ This transition was indispensable for the outstanding Soviet record of sustained resource mobilisation for war.

Different aspects of the Soviet economic system were therefore important at different stages of the war. Planning in the 'railway timetable' sense was not very important in the initial battle for survival; everything depended upon improvised leadership and mobilisation. But improvisation could only stave off defeat, and could not secure victory. To restore coordination of the civilian and defence sectors, to revive the production of steel, electricity and foodstuffs, and to allocate resources intelligently for these purposes required something more which only detailed planning could secure.

The Stalinist economic system, even in peacetime, is sometimes described as a 'sui generic war economy'. ${ }^{44}$ From the point of view of the experience of real fighting, this turned out to be a substantial simplification because in fact the economic system had to be significantly modified to fit it for protracted warfare. The informal system over which Stalin exercised personal domination performed certain essential functions of mobilisation for war in the second half of 1941. But associated

${ }^{42}$ On overmobilisation see Mark Harrison, 'Resource Mobilization for World War II: the USA, UK, USSR and Germany Compared', Economic History Review, 2nd ser , vol. 41, no. 1, 1988, pp. 187-9.

${ }^{43}$ Harrison, Soviet Planning, pp. 213-14.

${ }^{44}$ Oskar Lange, 'Role of Planning in Socialist Economy', in Lange (ed.), Problems of Political Economy of Socialism, New Delhi, 1962, p. 18. 
with it were also heavy penalties. Its relegation in favour of the formal model at the end of 1942 was later judged, even by the relatively conservative standards of the Brezhnev years, to demonstrate inherent limits on the effectiveness of naked authority and management by decree. ${ }^{45}$

\section{Conclusions}

Three conclusions may be drawn from this study of the 'test of war'.

First, among the objectives of Stalin's prewar policies of rapid industrialisation and collectivisation, and the new economic system associated with them, was the enhancement of Soviet national security. The appropriateness of these policies' design can be verified in the light of World War II. The level of Soviet industrial development achieved by 1941 was, in a broad sense, one of the keys to Soviet victory in war. However, this does not necessarily apply to forced rapid industrialisation on the Stalinist pattern. This pattern entailed huge costs in both peace and war, arising from its lack of balance with regard to both pace and spatial distribution. From a wartime perspective the worst result was the vulnerable concentration of strategic enterprises in western border regions. Associated with this was the need to carry out in war time the tasks of dispersal which should have been carried out in time of peace. It may be that, from the point of view of the needs of war in 1941-5, the case for a degree of forced-march industrialisation in the prewar years cannot be entirely discounted. However, the real extent to which the pace was forced under Stalinist policies looks, in retrospect, counterproductive in war as in peace.

Second, wartime experience did not prove an independent source of validation of the prewar agrarian policies of food procurement and collectivisation, which revealed essential weaknesses. The latter were no different from the weaknesses already evident in peace time. The requirements of wartime food policy forced essential modifications of the prewar kolkhoz regime. Often these were in the direction of relaxation. Where a course of intensification was adopted, this may have been counterproductive in terms of war aims. However, an unregulated system of smallscale peasant farming would probably have let the war economy down, too. What was needed for World War II was an intermediate regime based on an administrative system for procurement of surpluses subject to institutionalised limits, coupled with encouragement of traditional interfamily cooperation in production.

Third, in the 'test of war' the economic system revealed both strengths and weaknesses. The informal management system rooted in personal dictatorship played a particularly significant role in the first months of fighting. A more relaxed, coordinated and orderly system might have allowed greater economic equilibrium in the period of adaptation to war, but what mattered in 1941 was speed, not smoothness-guns, shells, tanks and aircraft, not efficiency of coordination. However, the informal system also revealed essential weaknesses in wartime. This

\footnotetext{
${ }^{45}$ Harrison, Soviet Planning, pp. 235-42.
} 
system had left the Soviet Union unprepared at the moment of the war's onset; having won time back during the rest of 1941, in the following year it lost effectiveness again. During 1942 the economic crisis got worse, not better. Eventual stabilisation and sustained economic mobilisation required reversion to the formal management system based on the struggle of law-governed authority to suppress the informal system's dictatorial currents. If not the scale, then the sustained character of the Soviet Union's wartime economic mobilisation must be attributed to the formal management system.

In considering the weaknesses of the prewar Stalinist model revealed in war time, the reader should not be misled by the ease with which hindsight may be exercised. The findings above do not imply the availability of some easy institutional or policy 'fix' which could have been applied in 1941, or at some earlier date, and which could have significantly eased wartime burdens. The impact of Hitler's plan for aggressive war against the USSR was bound to be enormously costly in lives and assets under the most 'ideal' circumstances. Hindsight tells us, however, that the real circumstances of the Soviet war effort were not ideal. 